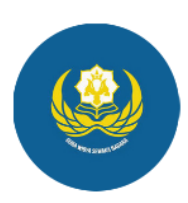

\title{
Ratio Analysis on Tiktok (Social Media) for Qualitative Research Using Explorative Methods
}

\author{
I Putu Hendika Permana, Ni Putu Suci Meinarni \\ STMIK STIKOM Indonesia \\ hendika@stiki-indonesia.ac.id, sucimeinarni@stiki-indonesia.ac.id
}

Published: $19 / 03 / 2021$

How to cite (in APA style):

Permana, I Putu Hendika., Meinarni, Ni Putu Suci (2021). Ratio Analysis on Tiktok (Social Media) for Qualitative Research Using Explorative Methods. Jurnal Ekonomi dan Bisnis Jagaditha, Vol. 8 (1), 30-38. doi: https://doi.org/10.22225/jj.8.1.2944.30-38

\begin{abstract}
Information and communication technology is considered important by users, one of its goals is to seek information and communicate remotely through social media. Social media aims to provide convenience in terms of communicating so that it has an impact on users, either it positive or negative perceptions. Currently, Tiktok social media become most popular application. This research was conducted to find the ratios that will be used to systematically show the performance of the Tiktok account. This study uses an exploratory method to find the variables contained in the Tiktok account. These variables will be compared so as to find the relevant ratios to show the performance of a Tiktok account. The results of this study is that the tiktok account has 7 variables and find then 17 ratios that can be used to assess, measure and compare the credibility of a Tiktok account.
\end{abstract}

Keyword: Credibility of Tiktok's Account, Social Media, Tiktok, Tiktok's Ratio

\section{INTRODUCTION}

Information

and

communication technology is considered important by users, where one of the goals is to seek information and communicate via social media. The existence of this means of communication has had a significant impact in various fields such as social, economic, education and other fields. Internet users use social media to expand their friendship by publishing their personal lives to these networks. Social media provides an opportunity for users to comment and share unlimited information for free (Ruth \& Candraningrum, 2020).

The sophistication of technology to seek information has increasingly caused the newspaper and television media to lose many audiences, since print and broadcast media as promotional media are facing big challenges (Mukaida et al., 2015). With the rapid development of social media technology, it has had an impact on communication sites, from initially just email and chat, now there are many social media networks that can be used as a means of communication. For example,
Facebook, Tiktok, Instagram, twitter, Telegram, Snapchat.

One of the most popular social media is Tiktok. Tiktok is an application launched in September 2016 by Zhang Yiming, the founder of Toutiao. The application gives users access to create their own short music videos. Throughout 2018 to 2019, Tiktok established itself as the most downloaded application, namely 45.8 million times. With such a large number, it beat other popular applications such as Instagram and Whatsapp (Aji, 2018). The Tiktok application can be used to view video content created by other Tiktok accounts besides that you can also see how many Likes, comments and the number of shares of the video. Tiktok social media has several advantages including filters and effects that do not exist in other social media applications, Tiktok can also be used as a business medium when a brand is made capable of climbing hashtags and the latest trends, of course there are more opportunities to successfully sell a product. Apart from the advantages of TikTok, it also has its disadvantages, namely, the content that is made is not restricted or too free for all users, so that 
TikTok social media is not well accessible for children.

The euphoria of using Tiktok's account, makes researchers want to assess the accounts on Tiktok social media. Several studies have been conducted related to the use of Tiktok's social media. For example, such as Tiktok as an information medium, Tiktok as a literary skill learning, management of medical officers in handling Covid-19 patients through Tiktok social media, Tiktok as a place to increase selfconfidence.

From the research that has been done, there is no research that has examined the ratios contained in the accounts on Tiktok social media. These ratios can later be used to conduct quantitative analysis or research. Several aspects that can be assessed using the ratios of the results of the study, namely, the first is the ingestion in the Tiktok account, whether the ingetsmen from the account are good or not. Second, these ratios can also be used to measure the credibility of the Tiktok account. And third, to assess the performance of the content or posts posted on the Tiktok account. This research was conducted to find the ratios that will be used to systematically show the performance of the Tiktok account.

\section{CONCEPTUAL FRAMEWORK}

Social media provides freedom for users to post the desired content. Various popular social media applications and have different facilities and criteria (Susilowati, 2018). Of the many social media applications, Tiktok is the most used application. Tiktok is a social media that has quite a lot of active users. Tiktok provides content in the form of videos that can be accessed by all users. Tiktok social media users are not only from millennial circles but also from companies, organizations and governments who use social media as promotional stalls or providing information.

Environmental influences that can make someone interested in social media, such as social media users who see the Tiktok application are based on how many people around them access the Tiktok application (Bulele \& Wibowo, 2020). From this statement, it is evident that users who were initially not interested eventually become interested, and get the benefits they need such as being able to expand their network of friends, get interesting entertainment so that they provide information.

Tiktok social media can also help increase a person's confidence by uploading video content that is created. Adawiyah (2020) explains the different consequences of using media. Every individual has a different level of need in using the media, one of the needs that someone wants to meet is about increasing selfconfidence.

Tiktok social media applications are currently increasingly in demand, so they feel they have power or influence in the industry with the quality of the account that determines the level and credibility of the account owner. The credibility of an account is an important thing for various purposes. Credibility can be measured by the performance of an account which can be measured systematically. In measuring performance, a measurement scale is needed which is stated in the ratios. According to Sugiyono (2010), various kinds of measurement scales, namely: nominal scale, ordinal scale, interval scale, and ratio scale. The measurement scale will generate data in the form of a ratio.

\section{METHOD}

The widespread use of Tiktok's social media has led to a new phenomenon that is used by companies or individuals to interact and communicate. This condition is used to gain followers by doing innovation, marketing and communicating online. There are several categories of users of Tiktok social media accounts such as:

- Personal categories, for example: Artists, Figures, Public Officials, Celebrities, Professional Workers and so on.

- Organizational categories, for example: Communities, Political Parties, NGOs (Non-Governmental Organizations), NPOs (Nonprofit Organizations).

- Company categories for example: all forms of companies that aim to generate profits.

This exploratory type research will examine all categories of Tiktok social media users. with the aim of deepening knowledge and looking for new ideas about a particular phenomenon, describing social phenomena, and explaining how a social phenomenon occurs. Exploratory research is used to formulate 
problems in more detail or describe hypotheses instead of testing hypotheses (Mudjiyanto, 2018). This study aims to find variables on Tiktok social media which will later be formulated into ratios. Tiktok accounts that can be analyzed must meet the technical requirements of the Tiktok settings to be analyzed, namely:

- Is an account with a public or non-private status so that it can be accessed without having to ask for confirmation from the account owner.

- The comment column is not disabled so that the comment column defines a number that indicates the number of comments on a post.

- The account owner gives freedom to other users to be able to share (share) video content posts created with other users.

This study aims to be a reference for quantitative research so that the variable to be analyzed is an object that has a value in the form of a number so that it can be calculated in the process of making or formulating it as a ratio. The following is the process of finding variables on Tiktok.

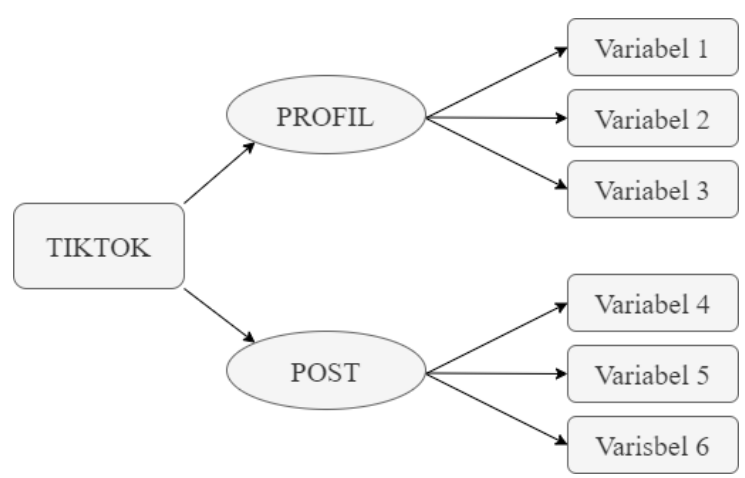

Image 1

Finding Variables on Tiktok

(Source: Self-Processed Image)

The ratio is the ratio of one number to other numbers that form a relationship. The ratio is a number depicted in the comparison of a pattern with other patterns and expressed as a percentage (Hanggara, 2020). In determining a ratio, a minimum of 2 variables are required to be compared to produce a value whose final result is expressed as a percentage. Of all the variables found will be compared with all the variables found and then tested for their relevance so that it can be determined whether the comparison between the two variables can be categorized as a ratio.

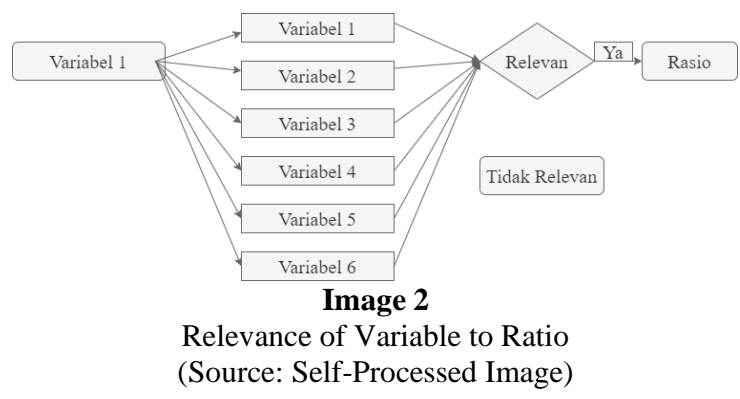

In the picture the relevance of the variable to the ratio shows that variable 1 is compared to all other variables so that it finds 2 relevant variables to be used as a ratio. After variable one is finished in the analysis, then it is followed by variable 2 as in the following figure.

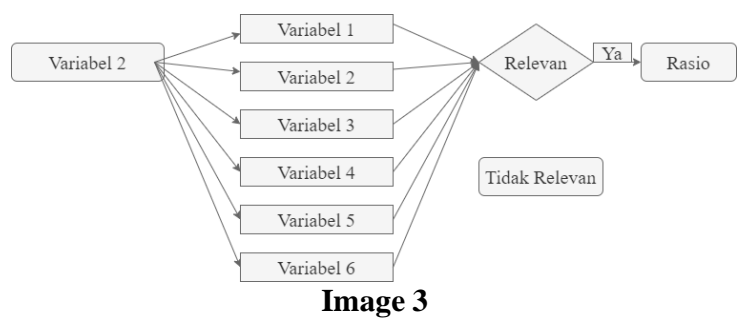

Relevance of Variable 2 to Other Variables (Source: Self-Processed Image)

In the picture, variable 2 is compared to all other variables, which shows the comparison between variable 2 and all other variables, so as to find 2 relevant variables to be used as a ratio. After variable two is finished in the analysis, it is followed by variables three, four, five and so on until all variables are compared with all other variables. The relevance of the ratio is shown by analyzing the effect of the ratio on the assessment of the Tiktok account being analyzed. The ratio is included in the irrelevant category if the comparison between 2 variables has the following conditions:

- Comparison between the same variables.

- The first variable tends to have a large value compared to the second variable.

- The two variables are not influenced or determined by the public.

- The two variables are not appropriate or appropriate to compare. 


\section{RESULT AND DISCUSSION}

The characteristics that are applied to TikTok social media are following other user accounts, or having followers on the user's account. The main use of Tiktok is as a place to upload various video content to other users. Tiktok social media users can get Likes and comments from other users from uploaded videos, and Tiktok social media users can also give Likes and comments on a video uploaded by another account.

By analyzing a Tiktok account, variables that have a value are found, namely:

- Account (Likes, Followers and Following). This variable as seen as image below.

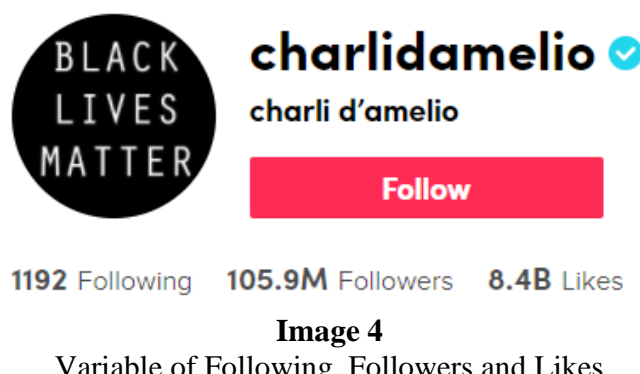

(Source: https://www.tiktok.com/@ charlidamelio?lang=en $/$, accessed 15-01-2021)

- Post (Video Likes, Video Comment, Video Share and Video Views). This variable as seen as image below.

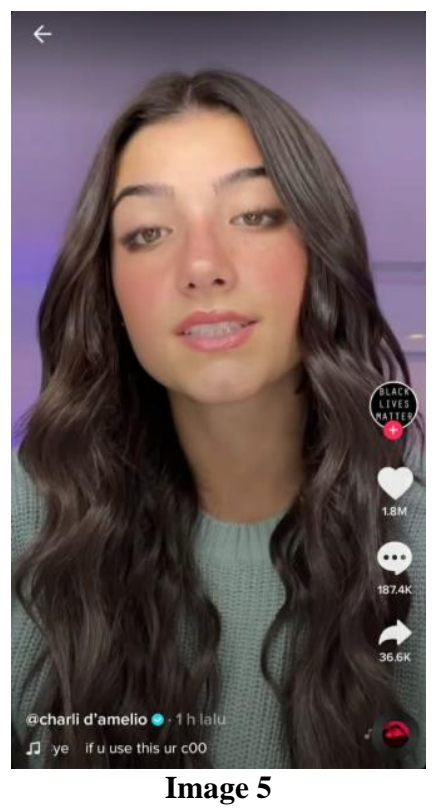

Video Likes, Comments and Share Variables (Source:https://www.tiktok.com/@ charlidamelio/video/691 7422554504301830?lang=en / , accessed 15-01-2021)

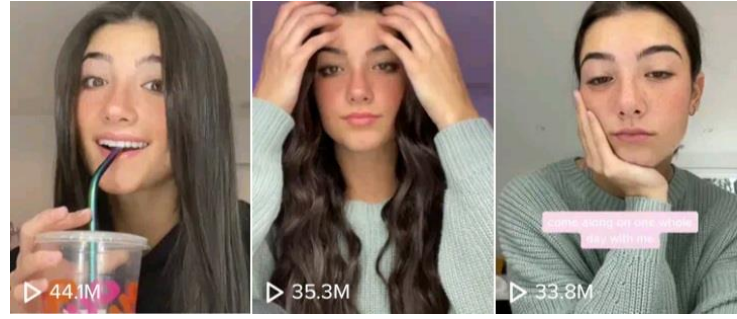

Image 9

Video Views Variabel

(Source: https://www.tiktok.com/@ charlidamelio?lang=en / accessed 15-01-2021)

There are 7 variables that will go through the next analysis process, namely the comparison between variables and testing the relevance between two comparisons of variables. The seven variables are:

- Likes

- Followers

- Following

- Video Likes

- Video Comments

- Video Share

- Video Views

Table 1.

Comparison between Variables and the Analisys Relevance between Variables

\begin{tabular}{|c|c|c|c|}
\hline Variable 1 & Variable 2 & Relevance & Reason \\
\hline Likes & Likes & $\begin{array}{l}\text { Not } \\
\text { Relevant }\end{array}$ & $\begin{array}{l}\text { Because } \\
\text { the two } \\
\text { variables } \\
\text { are the } \\
\text { same }\end{array}$ \\
\hline Likes & Followers & $\begin{array}{l}\text { Not } \\
\text { Relevant }\end{array}$ & $\begin{array}{l}\text { Variable } 1 \\
\text { tends to } \\
\text { be bigger } \\
\text { than } \\
\text { variable } 2\end{array}$ \\
\hline Likes & Following & $\begin{array}{l}\text { Not } \\
\text { Relevant }\end{array}$ & $\begin{array}{l}\text { Variable } 1 \\
\text { tends to } \\
\text { be bigger } \\
\text { than } \\
\text { variable } 2\end{array}$ \\
\hline Likes & $\begin{array}{l}\text { Video } \\
\text { Likes }\end{array}$ & $\begin{array}{l}\text { Not } \\
\text { Relevant }\end{array}$ & $\begin{array}{l}\text { Variable } 1 \\
\text { tends to } \\
\text { be bigger } \\
\text { than } \\
\text { variable } 2\end{array}$ \\
\hline Likes & $\begin{array}{l}\text { Video } \\
\text { Comment }\end{array}$ & $\begin{array}{l}\text { Not } \\
\text { Relevant }\end{array}$ & $\begin{array}{l}\text { Variable } 1 \\
\text { tends to } \\
\text { be bigger } \\
\text { than } \\
\text { variable } 2\end{array}$ \\
\hline Likes & $\begin{array}{l}\text { Video } \\
\text { Share }\end{array}$ & $\begin{array}{l}\text { Not } \\
\text { Relevant }\end{array}$ & $\begin{array}{l}\text { Variable } 1 \\
\text { tends to } \\
\text { be bigger } \\
\text { than }\end{array}$ \\
\hline
\end{tabular}


Ratio Analysis on Tiktok (Social Media) for Qualitative Research Using Explorative Methods

\begin{tabular}{|c|c|c|c|c|c|c|c|}
\hline & & & variable 2 & & & & \multirow[t]{2}{*}{ following } \\
\hline \multirow[t]{4}{*}{ Likes } & \multirow{4}{*}{$\begin{array}{l}\text { Video } \\
\text { Views }\end{array}$} & \multirow{4}{*}{$\begin{array}{l}\text { Not } \\
\text { Relevant }\end{array}$} & \multirow{4}{*}{$\begin{array}{l}\text { Variable } 1 \\
\text { tends to } \\
\text { be bigger } \\
\text { than } \\
\text { variable } 2\end{array}$} & Video & \multirow[t]{2}{*}{ Likes } & \multirow[t]{2}{*}{ Relevant } & \\
\hline & & & & Likes & & & \\
\hline & & & & $\begin{array}{l}\text { Video } \\
\text { Likes }\end{array}$ & Followers & Relevant & \\
\hline & & & & Video & Following & Not & Variable 1 \\
\hline Followers & Likes & Relevant & & Likes & & Relevant & tends to \\
\hline \multirow[t]{2}{*}{ Followers } & \multirow[t]{2}{*}{ Followers } & \multirow[t]{2}{*}{$\begin{array}{l}\text { Not } \\
\text { Relevant }\end{array}$} & \multirow{2}{*}{$\begin{array}{l}\text { Because } \\
\text { the two } \\
\text { variables } \\
\text { are the } \\
\text { same }\end{array}$} & & & & $\begin{array}{l}\text { be bigger } \\
\text { than } \\
\text { variable } 2\end{array}$ \\
\hline & & & & $\begin{array}{l}\text { Video } \\
\text { Likes }\end{array}$ & $\begin{array}{l}\text { Video } \\
\text { Likes }\end{array}$ & $\begin{array}{l}\text { Not } \\
\text { Relevant }\end{array}$ & $\begin{array}{l}\text { Because } \\
\text { the two }\end{array}$ \\
\hline \multirow[t]{2}{*}{ Followers } & \multirow[t]{2}{*}{ Following } & \multirow[t]{2}{*}{$\begin{array}{l}\text { Not } \\
\text { Relevant }\end{array}$} & \multirow{2}{*}{$\begin{array}{l}\text { Variable } 1 \\
\text { tends to } \\
\text { be bigger } \\
\text { than } \\
\text { variable } 2\end{array}$} & & & & $\begin{array}{l}\text { variables } \\
\text { are the } \\
\text { same }\end{array}$ \\
\hline & & & & $\begin{array}{l}\text { Video } \\
\text { Likes }\end{array}$ & $\begin{array}{l}\text { Video } \\
\text { Comment }\end{array}$ & $\begin{array}{l}\text { Not } \\
\text { Relevant }\end{array}$ & $\begin{array}{l}\text { Variable } 1 \\
\text { tends to }\end{array}$ \\
\hline \multirow[t]{2}{*}{ Followers } & \multirow[t]{2}{*}{$\begin{array}{l}\text { Video } \\
\text { Likes }\end{array}$} & \multirow[t]{2}{*}{$\begin{array}{l}\text { Not } \\
\text { Relevant }\end{array}$} & \multirow{2}{*}{$\begin{array}{l}\text { Variable } 1 \\
\text { tends to } \\
\text { be bigger } \\
\text { than } \\
\text { variable } 2\end{array}$} & & & & $\begin{array}{l}\text { be bigger } \\
\text { than } \\
\text { variable } 2\end{array}$ \\
\hline & & & & $\begin{array}{l}\text { Video } \\
\text { Likes }\end{array}$ & $\begin{array}{l}\text { Video } \\
\text { Share }\end{array}$ & $\begin{array}{l}\text { Not } \\
\text { Relevant }\end{array}$ & $\begin{array}{l}\text { Variable } 1 \\
\text { tends to }\end{array}$ \\
\hline \multirow[t]{2}{*}{ Followers } & \multirow[t]{2}{*}{$\begin{array}{l}\text { Video } \\
\text { Comment }\end{array}$} & \multirow[t]{2}{*}{$\begin{array}{l}\text { Not } \\
\text { Relevant }\end{array}$} & \multirow{2}{*}{$\begin{array}{l}\text { Variable } 1 \\
\text { tends to } \\
\text { be bigger } \\
\text { than } \\
\text { variable } 2\end{array}$} & & & & $\begin{array}{l}\text { be bigger } \\
\text { than } \\
\text { variable } 2\end{array}$ \\
\hline & & & & $\begin{array}{l}\text { Video } \\
\text { Likes }\end{array}$ & $\begin{array}{l}\text { Video } \\
\text { Views }\end{array}$ & Relevant & \\
\hline Followers & $\begin{array}{l}\text { Video } \\
\text { Share }\end{array}$ & $\begin{array}{l}\text { Not } \\
\text { Relevant }\end{array}$ & $\begin{array}{l}\text { Variable } 1 \\
\text { tends to } \\
\text { be bigger } \\
\text { than } \\
\text { variable } 2\end{array}$ & $\begin{array}{l}\text { Video } \\
\text { Comment }\end{array}$ & Likes & Relevant & $\begin{array}{l}\text { Because } \\
\text { the two } \\
\text { variables } \\
\text { are the } \\
\text { same }\end{array}$ \\
\hline Followers & $\begin{array}{l}\text { Video } \\
\text { Views }\end{array}$ & $\begin{array}{l}\text { Not } \\
\text { Relevant }\end{array}$ & $\begin{array}{l}\text { Variable } 1 \\
\text { tends to } \\
\text { be bigger } \\
\text { than } \\
\text { variable } 2\end{array}$ & $\begin{array}{l}\text { Video } \\
\text { Comment }\end{array}$ & Followers & Relevant & $\begin{array}{l}\text { Variable } 1 \\
\text { tends to } \\
\text { be bigger } \\
\text { than } \\
\text { variable } 2\end{array}$ \\
\hline \multirow{4}{*}{$\begin{array}{l}\text { Following } \\
\text { Following } \\
\text { Following }\end{array}$} & Likes & Relevant & & Video & Following & Not & Post \\
\hline & Followers & Relevant & & Comment & & Relevant & interaction \\
\hline & Following & $\begin{array}{l}\text { Not } \\
\text { Relevant }\end{array}$ & $\begin{array}{l}\text { Because } \\
\text { the two } \\
\text { variables }\end{array}$ & & & & $\begin{array}{l}\text { have no } \\
\text { effect on } \\
\text { following }\end{array}$ \\
\hline & & & $\begin{array}{l}\text { are the } \\
\text { same }\end{array}$ & $\begin{array}{l}\text { Video } \\
\text { Comment }\end{array}$ & $\begin{array}{l}\text { Video } \\
\text { Likes }\end{array}$ & Relevant & \\
\hline Following & $\begin{array}{l}\text { Video } \\
\text { Likes }\end{array}$ & $\begin{array}{l}\text { Not } \\
\text { Relevant }\end{array}$ & $\begin{array}{l}\text { Post } \\
\text { interaction } \\
\text { have no } \\
\text { effect on } \\
\text { following }\end{array}$ & $\begin{array}{l}\text { Video } \\
\text { Comment }\end{array}$ & $\begin{array}{l}\text { Video } \\
\text { Comment }\end{array}$ & $\begin{array}{l}\text { Not } \\
\text { Relevant }\end{array}$ & $\begin{array}{l}\text { Because } \\
\text { the two } \\
\text { variables } \\
\text { are the } \\
\text { same }\end{array}$ \\
\hline Following & $\begin{array}{l}\text { Video } \\
\text { Comment }\end{array}$ & $\begin{array}{l}\text { Not } \\
\text { Relevant }\end{array}$ & $\begin{array}{l}\text { Post } \\
\text { interaction } \\
\text { have no } \\
\text { effect on } \\
\text { following }\end{array}$ & $\begin{array}{l}\text { Video } \\
\text { Comment }\end{array}$ & $\begin{array}{l}\text { Video } \\
\text { Share }\end{array}$ & $\begin{array}{l}\text { Not } \\
\text { Relevant }\end{array}$ & $\begin{array}{l}\text { Variable } 1 \\
\text { tends to } \\
\text { be bigger } \\
\text { than } \\
\text { variable } 2\end{array}$ \\
\hline Following & $\begin{array}{l}\text { Video } \\
\text { Share }\end{array}$ & $\begin{array}{l}\text { Not } \\
\text { Relevant }\end{array}$ & $\begin{array}{l}\text { Post } \\
\text { interaction }\end{array}$ & $\begin{array}{l}\text { Video } \\
\text { Comment }\end{array}$ & $\begin{array}{l}\text { Video } \\
\text { Views }\end{array}$ & Relevant & \\
\hline & & & $\begin{array}{ll}\text { have no } \\
\text { effect on }\end{array}$ & $\begin{array}{l}\text { Video } \\
\text { Share }\end{array}$ & Likes & Relevant & \\
\hline & & & following & Video & Followers & Relevant & \\
\hline Following & Video & Not & Post & Share & & & \\
\hline & Views & Relevant & $\begin{array}{l}\text { interaction } \\
\text { have no } \\
\text { effect on }\end{array}$ & $\begin{array}{l}\text { Video } \\
\text { Share }\end{array}$ & Following & $\begin{array}{l}\text { Not } \\
\text { Relevant }\end{array}$ & $\begin{array}{l}\text { Post } \\
\text { interaction } \\
\text { have no no }\end{array}$ \\
\hline
\end{tabular}


Ratio Analysis on Tiktok (Social Media) for Qualitative Research Using Explorative Methods

\begin{tabular}{|c|c|c|c|}
\hline & & & $\begin{array}{l}\text { effect on } \\
\text { following }\end{array}$ \\
\hline Video & Video & \multirow[t]{2}{*}{ Relevant } & \\
\hline Share & Likes & & \\
\hline Video & Video & \multirow[t]{2}{*}{ Relevant } & \\
\hline Share & Comment & & \\
\hline Video & Video & Not & Because \\
\hline Share & Share & Relevant & $\begin{array}{l}\text { the two } \\
\text { variables } \\
\text { are the } \\
\text { same }\end{array}$ \\
\hline Video & Video & \multirow[t]{2}{*}{ Relevant } & \\
\hline Share & Views & & \\
\hline $\begin{array}{l}\text { Video } \\
\text { Views }\end{array}$ & Likes & Relevant & \\
\hline $\begin{array}{l}\text { Video } \\
\text { Views }\end{array}$ & Followers & Relevant & \\
\hline $\begin{array}{l}\text { Video } \\
\text { Views }\end{array}$ & Following & $\begin{array}{l}\text { Not } \\
\text { Relevant }\end{array}$ & $\begin{array}{l}\text { Variable } 1 \\
\text { tends to } \\
\text { be bigger } \\
\text { than } \\
\text { variable } 2\end{array}$ \\
\hline Video & Video & Not & \multirow[b]{2}{*}{$\begin{array}{l}\text { Variable } 1 \\
\text { tends to } \\
\text { be bigger } \\
\text { than } \\
\text { variable } 2\end{array}$} \\
\hline Views & Likes & Relevant & \\
\hline Video & Video & Not & \multirow[b]{2}{*}{$\begin{array}{l}\text { Variable } 1 \\
\text { tends to } \\
\text { be bigger } \\
\text { than } \\
\text { variable } 2\end{array}$} \\
\hline Views & Comment & Relevant & \\
\hline Video & Video & Not & \multirow[b]{2}{*}{$\begin{array}{l}\text { Variable } 1 \\
\text { tends to } \\
\text { be bigger } \\
\text { than } \\
\text { variable } 2\end{array}$} \\
\hline Views & Share & Relevant & \\
\hline Video & Video & Not & \multirow{2}{*}{$\begin{array}{l}\text { Because } \\
\text { the two } \\
\text { variable } \\
\text { are the } \\
\text { same }\end{array}$} \\
\hline Views & Views & Relevant & \\
\hline
\end{tabular}

(Source: Self-Processed Data)

Table 2.

Relevant Data to be Formulated into Ratio

\begin{tabular}{ccccl}
\hline No & Variable 1 & Variable 2 & Relevance & \multicolumn{1}{c}{ Ratio } \\
\hline 1 & Followers & Likes & Relevant & $\begin{array}{l}\text { Followers } \\
\text { to Likes } \\
\text { Ratio }\end{array}$ \\
\hline 2 & Following & Likes & Relevant & $\begin{array}{l}\text { Following } \\
\text { to Likes } \\
\text { Ratio }\end{array}$ \\
\hline 3 & Following & Follow & Relevant & $\begin{array}{l}\text { Following } \\
\text { to } \\
\end{array}$ \\
& & ers & & $\begin{array}{l}\text { Followers } \\
\text { Ratio }\end{array}$ \\
\hline 4 & Video Likes & Likes & Relevant & $\begin{array}{l}\text { Video } \\
\text { Likes to } \\
\end{array}$ \\
& & & & $\begin{array}{l}\text { Likes } \\
\text { Ratio }\end{array}$ \\
\hline 5 & Video Likes & Follow & Relevant & $\begin{array}{l}\text { Video } \\
\text { Likes to }\end{array}$ \\
\hline
\end{tabular}

\begin{tabular}{|c|c|c|c|c|}
\hline & & & & $\begin{array}{l}\text { Followers } \\
\text { Ratio }\end{array}$ \\
\hline \multirow[t]{5}{*}{6} & Video Likes & Video & Relevant & Video \\
\hline & & Views & & Likes \\
\hline & & & & Video \\
\hline & & & & Views \\
\hline & & & & Ratio \\
\hline \multirow[t]{4}{*}{7} & Video & Likes & Relevant & Video \\
\hline & Comment & & & Comment \\
\hline & & & & $\mathrm{s}$ to Likes \\
\hline & & & & Ratio \\
\hline \multirow[t]{5}{*}{8} & Video & Follow & Relevant & Video \\
\hline & Comment & ers & & Comment \\
\hline & & & & $\mathrm{s}$ to \\
\hline & & & & Followers \\
\hline & & & & Ratio \\
\hline \multirow[t]{5}{*}{9} & Video & Video & Relevant & Video \\
\hline & Comment & Likes & & Comment \\
\hline & & & & $\mathrm{s}$ to Video \\
\hline & & & & Likes \\
\hline & & & & Ratio \\
\hline \multirow[t]{5}{*}{10} & Video & Video & Relevant & Video \\
\hline & Comment & Views & & Comment \\
\hline & & & & $\mathrm{s}$ to Video \\
\hline & & & & Views \\
\hline & & & & Ratio \\
\hline \multirow[t]{4}{*}{11} & Video Share & Likes & Relevant & Video \\
\hline & & & & Share \\
\hline & & & & Likes \\
\hline & & & & Ratio \\
\hline \multirow[t]{4}{*}{12} & Video Share & Follow & Relevant & Video \\
\hline & & ers & & Share to \\
\hline & & & & Followers \\
\hline & & & & Ratio \\
\hline \multirow[t]{5}{*}{13} & Video Share & Video & Relevant & Video \\
\hline & & Likes & & Share to \\
\hline & & & & Video \\
\hline & & & & Likes \\
\hline & & & & Ratio \\
\hline \multirow[t]{4}{*}{14} & Video Share & Video & Relevant & Video \\
\hline & & Comm & & Share \\
\hline & & ent & & Video \\
\hline & & & & Comment \\
\hline \multirow{4}{*}{15} & Video Share & Video & Relevant & Video \\
\hline & & Views & & Share to \\
\hline & & & & Video \\
\hline & & & & Comment \\
\hline \multirow{4}{*}{16} & Video & Likes & Relevant & Video \\
\hline & Views & & & Share \\
\hline & & & & Likes \\
\hline & & & & Ratio \\
\hline \multirow[t]{4}{*}{17} & Video & Follow & Relevant & Video \\
\hline & Views & ers & & Views to \\
\hline & & & & Followers \\
\hline & & & & Ratio \\
\hline
\end{tabular}

Details explanation on each found ratio:

- Followers to Likes Ratio (FLR) 
The ratio of the number of followers to the number of likes. This ratio shows the number of performance of posted content so that you find the results of the number of Likes for each post, which causes someone to follow (follow) the account. The weakness of this ratio is that the resulting data has potential or may not be comparable because these two variables have a percentage determined by the public and both have the value to create a wellperforming account. The higher the number of Likes generated, the better the performance of the Tiktok account will be.

- Following to Likes Ratio

The ratio of the number of Following to the number of Likes. This ratio shows the percentage of the number of following is smaller than the number of likes. The characteristic of this ratio is that the smaller the ratio, the better the performance of the Tiktok account.

- Following to Followers Ratio

The ratio of the number of Following to the number of Followers. This ratio shows the ratio of the number of accounts that are followed with the number of accounts that are following (followers). The weakness of this ratio is that the data generated has the potential or may not be compared to other accounts because the account owner can add or subtract the following so of course the resulting ratio calculation will change. The characteristic of this ratio is that the smaller the ratio number, the better the performance of a Tiktok account.

- Video Likes to Likes Ratio

The ratio of the number of video likes to the number of likes. This ratio shows the ability for video likes from a post to generate more likes than the number of likes. The characteristic of this ratio is that the greater the ratio, the better the performance of a Tiktok account.

- Video Likes to Followers Ratio

The ratio of the number of video likes to the number of followers this ratio shows the ability of a video post to generate likes compared to the number of followers it has. Likes on video posts are not only generated from followers, but can also be generated from non-followers, so this ratio cannot be considered as a direct comparison between Likes and followers. This ratio describes the ability or performance of a video post when viewed from the parameter of the number of followers. The characteristic of this ratio is that the greater the ratio, the better the performance of a Tiktok account.

- Video Likes to Video Views Ratio

The ratio to the number of video likes to the number of video views. The ratio shows the success rate of a video post converting views into likes the higher the percentage in this ratio, the better the performance of the video post. The characteristic of this ratio is that the greater the ratio, the better the performance of a TikTok account will be.

- Video Comments to Likes Ratio

The ratio of the number of video comments to the number of likes. This ratio shows the ability for a video post to generate comments compared to the percentage of Likes on the account. The characteristic of this ratio is that the greater the ratio, the better the performance of the Tiktok account.

- Video Comments to Followers Ratio

The ratio of the number of video comments to the number of video likes. This ratio shows the percentage of comments compared to likes on a video post. The higher this ratio, the higher the interest (engagement) in the post. The characteristic of this ratio is that the greater the ratio number, the better the performance of a Tiktok account.

- Video Comments to Video Likes Ratio The ratio of the number of video shares to likes. This ratio shows the performance of the percentage of video shares compared to the likes of a post. The characteristic of this ratio is that the greater the number of video shares, the better the performance of a video post.

- Video Comments to Video Views Ratio The ratio of the number of video comments to the number video views. This ratio shows the success rate of a video post converting views into comments. The higher the percentage in this ratio, the better the performance of the video post. The characteristic of this ratio is that the 
greater the ratio, the better the performance of a TikTok account.

- Video Share to Likes Ratio

The ratio of the number of video shares to likes. This ratio shows the performance of the percentage of video shares compared to the likes of a post. The characteristic of this ratio is that the greater the number of video shares, the better the performance of a video post.

- Video Share to Followers Ratio

The ratio of the number of video shares to the number of followers. This ratio shows the percentage of video shares compared to followers. The higher the percentage of video shares, the greater someone's interest in the video content that is made. The characteristic of this ratio is that the greater the ratio, the better the Tiktok account's performance.

- Video Share to Video Likes Ratio.

This ratio shows the percentage of video shares compared to video likes. These two variables have an important role in an account because these two variables affect the good performance of an account.

- Video Share to Video Comments Ratio. This ratio shows the percentage of video shares against video comments. This ratio cannot be compared directly because video shares and video comments are not only obtained from followers but non-followers can also share and comment on the video content. the characteristic of this video is that the greater the ratio, the better the performance of a Tiktok account.

- Video Share to Video Views Ratio

The ratio of the number video share to the number of video views. This ratio shows the success rate of a video post in converting views into shares. The higher the percentage in this ratio, the better the performance of the video post. The characteristic of this ratio is that the greater the ratio, the better the performance of a TikTok account.

- Video Views to Likes Ratio

The ratio of the number of video views to the number of likes. this ratio shows the ability of a video post to convert views into likes. the higher percentage in the ratio, the better the performance of the video post.
The characteristic of this ratio is that the greater the ratio, the better the performance of a TikTok account.

- Video Views to Followers Ratio The ratio of the number of video views to the number of followers. This ratio shows the ability of a video post generate viewers (views) compared to the number of followers it has. Viewers (views) on video post are not only generated from followers, but can be generated from non-followers, so this ratio cannot be considered as a direct comparison between video views and followers. This ratio describes the ability of performance of a video post when viewed from the parameter of the number of followers. The characteristic of this ratio is that the greater the ratio number, the better the performance of a TikTok account.

\section{CONCLUSION}

This research was conducted to find the ratios found on Tiktok social media. This ratio was found by conducting research using a credibility assessment on a Tiktok account that can be assessed for its performance. The Tiktok account has 7 variables that can be compared so that it finds 17 relevant ratios that can be used as performance assessment parameters. The implication of finding this ratio is that researchers can then carry out quantitative research in measuring, assessing and comparing the accounts contained in Tiktok.

\section{SUGGESTION}

The suggestion for future research is to analyze and compare the performance between two or more accounts for similar accounts. To compare or assess the performance of an account, you must compare it with similar accounts. Case studies that can be taken for further research include: fashion companies, government agencies, political figures and so on.

\section{REFERENCES}

Adawiyah, D. P. R. (2020). Pengaruh Penggunaan Aplikasi TikTok Terhadap Kepercayaan Diri Remaja di Kabupaten Sampang. Jurnal Komunikasi, 14(2), 135-148.

Aji, W. N. (2018). Aplikasi Tiktok Sebagai Media Pembelajaran Bahasa dan Sastra Indonesia. 
Prosiding Seminar Nasional Pertemuan Ilmiah Bahasa Dan Sastra Indonesia, 431, 431-440.

Bulele, Y. N., \& Wibowo, T. (2020). Analisis Fenomena Sosial Media Dan Kaum Milenial: Studi Kasus Tiktok. In Conference on Business, Social Sciences and Innovation Technology (Vol. 1, Issue 1).

Hanggara, B. (2020). Pengaruh Rasio Keuangan Terhadap Financial Distress Pada Perusahaan Ritel Yang Terdaftar Di Bursa Efek Indonesia.

Mudjiyanto, B. (2018). Tipe Penelitian Eksploratif Komunikasi. Jurnal Studi Komunikasi Dan Media, 22(1), 65.

Mukaida, N., Sasaki, S., \& Baba, T. (2015). Id: 33. Cytokine, 76(1), 70.

Ruth, D., \& Candraningrum, D. A. (2020). Pengaruh Motif Penggunaan Media Baru Tiktok terhadap Personal Branding Generasi Milenial di Instagram. Koneksi, 4(2), 207.

Sugiyono, S. (2010). Metode Penelitian Kuantitatif dan Kualitatif dan R\&D. Jakarta: Sinar Grafika.

Susilowati. (2018). Pemanfaatan Aplikasi Tiktok Sebagai Personal Branding Di Instagram (Studi Deskriptif Kualitatif Pada Akun @ bowo_allpennliebe). Jurnal Komunikasi, 9(2), 176-185. 